\title{
PENERAPAN PRINSIP KEADILAN DALAM AKAD MUDHARABAH DI LEMBAGA KEUANGAN SYARIAH
}

\author{
Popon Srisusilawati dan Nanik Eprianti \\ Fakultas Syariah Universitas Islam Bandung \\ poponsrisusilawati@yahoo.co.id \& nanikeprianti@gmail.com
}

\begin{abstract}
Abstrak
$\mathrm{D}$ alam lembaga keuangan syariah telah diperkenalkan beberapa instrumen keuangan sebagai pengganti instrumen bunga. Instrumen tersebut adalah sebuah instrumen yang lebih mengedepankan prisip bagi hasil (profit and loss sharing). Keuntungan yang diperoleh dan kerugian yang diderita ditanggung secara bersama-sama oleh pihak yang melakukan transaksi. Oleh karena itu, kedua belah pihak, yang melakukan transaksi akan saling memperhatikan kemajuan dan kemunduran usaha yang dijalankan. Diantara prisnip bagi hasil yang paling menonjol dan bahkan paling populer adalah mudhârabah. Tujuan penelitian ini adalah, pertama, untuk mengetahui konsep teoritis tentang prinsip keadilan dan akad mudharabah dan kedua, untuk mengetahui penerapan prinsip keadilan dalam akad mudharabah di lembaga keuangan syariah. Metode pendekatan yang digunakan dalam penelitian ini adalah yuridis normatif dengan sifat penelitian deskriptif analisis. Jenis data yang digunakan dalam penelitian ini adalah jenis data primer dan sekunder. Penelitian ini digolongkan kepada jenis penelitian kualitiatif. Hasil penelitian menunjukan bahwa (1) Aristoteles membedakan keadilan itu menjadi 2 macam:,pertama, keadilan distributif; dan kedua, keadilan kumulatif. Mudhârabah adalah kerja sama antara pemilik dana atau penanam modal dan pengelola modal untuk melakukan usaha tertentu dengan pembagian keuntungan berdasarkan nisbah; (2) prinsip keadilan yang dapat diterapkan dalam akad mudharabah pada lembaga keuangan syariah.
\end{abstract}

Kata Kunci: Prinsip Keadilan, Lembaga Keuangan Syariah

\begin{abstract}
I $n$ the Islamic financial institutions have introduced several financial instruments in lieu of interest instruments. The instrument is an instrument that emphasizes the principle of profit sharing (profit and loss sharing). Profits earned and losses to be borne jointly by the parties to a transaction. Therefore, both parties to a transaction will be mutually keep track of progress and setbacks business carried. Among prisnip for the results of the most prominent and even the most popular is the mudaraba. The purpose of this study is, first, to determine the theoretical concepts of justice and mudharabah and secondly, to determine the application of the principle of fairness in mudharabah in Islamic financial institutions. The method used in this research is normative juridical by nature descriptive analysis. Data used in this study is a type of primary and secondary data. This study classified the types of Qualitative Research. The results showed that (1) Aristotle distinguishes justice into two kinds: first, distributive justice; and second, the cumulative justice. Mudharabah is a partnership between the owners of the fund or the investor and manager of capital to conduct certain business with profit sharing based on the ratio; (2)
\end{abstract}


the principle of fairness that can be applied in mudharabah on Islamic financial institutions.

Keywords: Principles Justice, Islamic Financial Institutions

\section{PENDAHULUAN}

\section{Latar Belakang}

Bank syariah memiliki peran sebagai lembaga perantara (intermediary) antara unit-unit ekonomi yang mengalami kelebihan dana (surplus units) dengan unit-unit lain yang mengalami kekurangan dana (deficit units). Melalui bank, kelebihan tersebut dapat disalurkan kepada pihak-pihak yang memerlukan sehingga memberikan manfaat kepada kedua belah pihak. ${ }^{1}$ Kulitas bank syariah sebagai lembara perantara ditentukan oleh kemampuan manajeman bank untuk melaksanakan perannya.

Dalam bank syariah, hubungan antara bank dengan nasabahnya bukan hubungan debitur dengan kreditur, melainkan hubungan kemitraan (partnership) antara penyandang dana dengan pengelola dana. Oleh karena itu, tingkat laba bank syariah tidak saja berpengaruh terhadap bagi hasil yang dapat diberikan kepada nasabah penyimpan dana. Hubungan kemitraan ini merupakan bagiannya yang khas dari proses berjalannya mekanisme bank syariah. ${ }^{2}$

Untuk memenuhi kebutuhan modal dan pembiayaan, bank syariah memiliki ketentuanketentuan yang berbeda dengan bank konvensional. Secara umum, piranti-piranti yang digunakan bank syariah terdiri atas tiga kategori, yaitu: pertama, produk penyaluran dana (financing), kedua, produk penghimpunan dana (funding), ketiga, produk jasa (service). ${ }^{3}$

Bank syariah diidentikan sebagai lembaga keuangan yang bebas dari bunga (interesfree). Instrumen bunga dalam lembaga keuangan syariah kerena diidentikan dengan riba yang diharamkan Islam. Padahal pada saat yang bersamaan, lambega keuangan konvensional tumbuh dan berkembang dengan bunga sebagai instrumen keuangan utamanya, tanpa ada bunga, maka lembaga keuangan konvensional tidak ada berkembang seperti saat ini. Persoalannya sekarang adalah, instrumen apa yang digunakan lembaga keuangan syariah apabila tidak menjadikan bunga sebagai instrumen keuangannya? ${ }^{4}$

Dalam lembaga keuangan syariah telah diperkenalkan beberapa instrumen keuangan sebagai pengganti instrumen bunga. Instrumen tersebut adalah sebuah instrumen yang lebih mengedepankan prisip bagi hasil (profit and loss sharing). Keuntungan yang diperoleh dan kerugian yang diderita ditanggung secara bersama-sama oleh pihak yang melakukan transaksi. Oleh karena itu, kedua belah pihak, yang melakukan transaksi akan saling memperhatikan kemajuan dan kemunduran usaha yang dijalankan. Diantara prisnip bagi hasil yang paling menonjol dan bahkan paling populer adalah mudhârabah. ${ }^{5}$

Secara sederhana mudhârabah dapat diartikan sebagai akad kerja sama antara pemilik dana atau penanam modal dan pengelola modal untuk melakukan usaha tertentu dengan pembagian keuntungan berdasarkan nisbah.

Menurut Warkum Sumitro, pada produk pembiayaan ini (baca: mudhârabah) diperlukan adanya jaminan. Bentuk jaminan yang diterapkan dalam bank syariah sama dengan bentuk jaminan yang diterapkan pada bank konvensional, yaitu terdiri atas jaminan perorangan dan jaminan kebendaan. ${ }^{6}$ Jaminan merupakan salah satu hal penting bagi bank syariah dalam

1 Zainul Arifin, Dasar-Dasar Manajemen Bank Syariah, Alvabet, Jakarta, 2002, hlm. 51.

2 Heri Sudarsono, Bank dan Lembaga Keuangan Syariah: Deskripsi dan Ilustrasi, EKONISIA, Yogyakarta, 2008, hlm. 63.

3 Ibid.

$4 \quad$ Yadi Janwari, Lembaga Keuangan Syariah, Remaja Rosdakarya, Bandung, 2015, hlm. 58.

$5 \quad$ Ibid.

6 Warkum Sumitro, Asas-Asas Perbankan Islam dan Lembaga-Lemabaga Terkait, PT RajaGrafindo Persada, 
rangka melaksanakan prinsip kehati-hatian (prudential pronciple). Prinsip kahati-hatian adalah pengendalian risiko melalui penerapan peraturan perundang-undangan dan ketentuan yang berlaku secara konsisten. ${ }^{7}$

Dalam bentuk kerja sama yang melibatkan antara pemodal dan pekerja ini, akad mudharabah perlu adanya keseimbangan guna mencapai nilai keadilan antara kedua belah pihak yang terlibat menjalankan akad mudharabah. Oleh karena itu, tulisan ini akan mengkaji keseimbangan serta keadilan diantara para pihak yang melakukan transaksi berupa akad mudharabah pada lembaga keuangan syariah.

\section{Rumusan Masalah}

a. Berdasarkan uraian di atas, maka identifikasi masalah dalam penulisan ini adalah sebagai berikut:

b. Bagaimana konsep teoritis tentang prinsip keadilan dan akad mudharabah?

c. Bagaimana penerapan prinsip keadilan dalam akad mudharabah di lembaga keuangan syariah?

\section{HASIL DAN PEMBAHASAN}

\section{Konsep Teoritis tentang Prinsip Keadilan dan Akad Mudrarabah}

\section{a. Konsep Teoritis tentang Prinsip Keadian}

Kata adil berasal dari bahasa Arab " $a l$ - 'adl" yang secara etimologis berarti tidak berat sebelah, tidak memihak, atau menyamaratakan yang satu dengan yang lain (almsawah). ${ }^{8}$ Menurut Rohi Baalbaki, kata "al- 'adl" diterjemahkan kedalam baha Inggris berarti justice, equitability, equitableness, impartiality, atau unbiasedness. ${ }^{9}$

Menurut Kamus Besar Bahasa Indonesia (KBBI) keadilan berarti sifat (perbuatan, perlakuan dsb) yang adil. Adil sendiri berarti: sama berat, tidak berat sebelah, tidak memihak, berpihak kepada yang benar, berpegang kepada kebenaran, sepatutnya, atau tidak sewenang-wenang. ${ }^{10}$ Dalam bahas Inggris justica berasal dari perkataan justicia yang kata asalnya ius atua jus. Perkataan jus berarti hukum atau hak. Dengan demikian salah satu pengertian justice adalah hukum (law). Menurut The Liang Gie, pemakaian yang cukup lazim kedua perkataan itu dianggap sepadan, misalnya pada istilah court of law (Mahkamah Hukum) dan court of justice (Mahkamah Keadilan) yang kedua-duanya menunjuk pada badan peradilan di negara Inggris. Dari makna keadilan sebagai law (hukum) kemudian berkembang arti dari kata justica sebagai lawfulness (sah menurut hukum). Sampai saat ini dalam bahasa Inggris perkataan justice masih dipakai sebagai sinonim dari law dan lawfulness. ${ }^{11}$

The Liang Gie berpendapat makna keadilan dalam hubungan yang lebih luas adalah fairness yang mendekati arti kelayakan. Ciri adil dalam arti layak atau pantas misalnya terdapat pada ungkapan fair price (harga yang pas) atau fair wage (upah yang layak). Ketika unsur atau pertimbangan moral lebih ditekankan pada pengertian keadilan dan dipandang lebih unggul daripada keadilan hukum (legal justice) semata-mata, tumbuhlah makna equity bagi justice. Equity mempunyai arti yang menyerupai kewajaran menurut nilai moral. Bila seluruh cita moralitas atau segenap kebijakan sebagai suatu keseluruhan tunggal seolah-olah dimasukkan dalam pengertian keadilan, maka maknanya lalu menjadi

Jakarta, 1996, hlm. 114.

Nindyo Pramono, Bunga Rampai Hukum Bisnis Aktual, PT Citra Aditya Bakti, Bandung, 2006, hlm. 262.

8 Abul Aziz Dahlan (ed al), Ensiklopedia Hukum Islam I, Ikhtiar Baru van Hoevem Jakarta, 2000, hlm. 25.

9 Rohi Baalbaki, AL-Mawrid, Dar al-'Ilmi lil Malayin, Beirut, 2007, hlm. 753.

10 Departemen Pendidikan Nasional, Kamus Besar Bahasa Indonesia, Balai Pustaka, Jakarta, 2005, hlm. 8.

11 The Liang Gie, Teori-Teori Keadilan, Supersukses, Yogyakarta, 1982, hlm. 15. 
righteousness yang bila diterjemahkan dapat berarti sebagai kebenaran yang berdasarkan kebaikan, bukan kebenaran sebagai suatu ilmu. ${ }^{12}$

Melalui uraian di atas, The Liang Gie kemudian merumuskan ciri atau sifat adil itu: Adil (justice), bersifat hukum (legal), sah menurut hukum (lawful), tidak memihak (impartial), sama hak (equal), layak (fair), wajar secara moral (equitable), atau benar secara moal (righteous).

Berbicara masalah keadilan maka tidak dapat melupakan filsuf Yunani yaitu Plato dan Aristoteles yang telah meletakkan dasar bagi keadilan dalam kaitannya dengan hukum positif. Sebagai penganut hukum Kodrat/ hukum alam ${ }^{13}$, dimana pada saat itu gagasan tentang keadilan adalah apa yang adil menurut hukum Kodratnya dan keadilan itu harus sesuai atau menurut keberlakuan hukumnya, maka Plato melihat keadilan dari sisi ilham, sedangkan Aristoteles beranjak dari latar belakang pemikiran model-model masyarakat, politik dan Undang-undang ${ }^{14}$.

Representasi Keadilan menurut Aristoteles yakni suatu kebijakan politik yang aturanaturannya menjadi dasar dari peraturan negara dan aturan-aturan ini merupakan ukuran tentang apa yang hak ${ }^{15}$. Aristoteles menyatakan: "Justice consists in treating equals equally dan unequals unequally, in proportion to their inequality". Berdasarkan analisa ilmiah yang dilakukan, Aristoteles membedakan keadilan itu menjadi 2 macam: pertama, Keadilan distributif (justitia distributiva) Keadilan distributif (justitia distributiva) ialah suatu keadilan yang memberikan keadilan kepada setiap orang didasarkan atas jasajasanya atau pembagian menurut haknya masing-masing. Keadilan distributif berperan dalam hubungan antara masyarakat dengan perorangan. Pengertian keadilan disini bukan berarti persamaan melainkan perbandingan; kedua, Keadilan kumulatif (justitia komulativa) atau keadilan korektif Keadilan kumulatif (justitia komulativa) ialah suatu keadilan yang diterima masing-masing anggota tanpa memperdulikan jasa masingmasing (persamaan) ${ }^{16}$.

Beranjak dari pembagian keadilan oleh Aritoteles, maka Thomas Aquinas selaku penerus dari Aristoteles, terkait masalah keadilan menurutnya yakni mengenai apa yang seharusnya/ sepatutnya bagi orang lain menurut sesuatu kesamaan proporsional ${ }^{17}$. Dengan demikian pada masa klasik ukuran masalah keadilan telah banyak dibicarakan dalam hubungan dengan hukum positif, untuk selanjutnya menjadi dasar pijakan dari

Ibid., hlm. 16.

13 Teori-teori Hukum Alam sejak Socrates hingga Francois Geny, tetap mempertahankan keadilan sebagai mahkota hukum. Teori Hukum Alam mengutamakan "the search for justice".

14 Aristoteles sebagai murid Plato ketika mempersoalkan tentang keadilan dalam kaitannya dengan hukum positif mengikuti pemikiran Plato, namun yang membedakan antara mereka, plato dalam mendekati persoalan keadilan dengan sudut pandang yang bersumber pada inspirasi, sementara aristoteles mendekati persoalan keadilan dengan sudut pandanga yang rasional (elemen masyarakat, politik dan undang-undang). Namun Plato dan Aristoteles sama-sama membangun konsep tentang nilai keutamaan (concept of virtue) yaitu tentang arah yang baik dan yang buruk berdasarkan nilai keadilan dan ketidakadilan.

15 Ulpianus memandang bahwa persoalan keadilan adalah kemauan yang bersifat tetap dan terusmenerus untuk memberikan kepada setiap orang apa yang semestinya untuknya (Iustitia est constans et perpetua voluntas ius suum cuique tribuendi - Ulpianus);

16 Aristoteles membedakan antara keadilan distrbutif dengan keadilan korektif, dimana Keadilan distributif berlaku dalam hukum public, hal yang terpenting adalah imbalan yang sama rata atas pencapaian yang sama rata, sedangkan keadilan korektif berlaku pada hukum perdata dan pidana, ketidaksetaraan disebabkan oleh adanya pelanggaran, dikoreksi dan dihilangkan

17 Thomas Aquinas dikenal sebagai penerus Aristoteles, ia membedakan 3 (tiga) jenis hukum yakni hukum abadi (lex actena), hukum kodrat (lex naturalis) dan hukum manusia/hukum positif (lex humana) 
para filusuf-filusuf abad Modern, seperti Jhon Rawl yang mengemukan tentang Teori Keadilan (a theory of justice) ${ }^{18}$.

\section{b. Konsep Teoritis tentang Akad Mudharabah}

Mudhârabah berasal dari kata dharb, yang artinya memukul atau berjalan. Pengertian memukul atau berjalan ini lebih tepatnya adalah proses seseorang menggerakan kakinya dalam menjalankan usahanya. ${ }^{19}$ Mudhârabah disebut juga qirâdh. Mudhârabah merupakan bahasa penduduk Irak, sedangkan menurut bahasa penduduk Hijaz disebut dengan istilah qirâdh.

Menurut Neneng Nurhasanah ${ }^{20}$, al-qirâdh, al-muqâradhah, dan al-mudhârabah adalah satu makna, yaitu penyerahan harta (modal) terhadap seseorang untuk diperniagan (digolangkan), sedangkan keuntunganya dibagikan di antara mereka (pemodal dan yang diberi modal). Qirâdh, dengan huruf Qaf yang dikasrahkan diambil dari kata al-qardhu yang artinya al-qath'u (potongan). Sebab pemilik memberikan potongan dari hartanya untuk diberikan kepada pengusaha agar menggolangkan harta tersebut, dan pengusaha akan memberikan potongan dari laba yang diperoleh. Qirâdh bisa diambil dari kata muqâradhah yang berarti al-musâwah (kesamaan), sebab pemilik modal dan pengusaha memiliki hak yang sama terhadap laba.

Orang Irak menyebutkanya dengan istilah mudhârabah, sebab setiap orang yang melakukan akad memiliki bagian dari laba, atau pengusaha harus mengadakan perjalanan dalam mengusahakan harta modal tersebut. Perjalanan tersebut dinamakan dharban $f_{i}$ al-safar. ${ }^{21}$

Adapun istilah mudhârabah atau qirâdh dikemukakan oleh para ulama dengan redaksi yang berbeda-beda, adapun uraiannya adalah sebagai berikut:

Menurut mayoritas fukaha, mudhârabah ialah:"

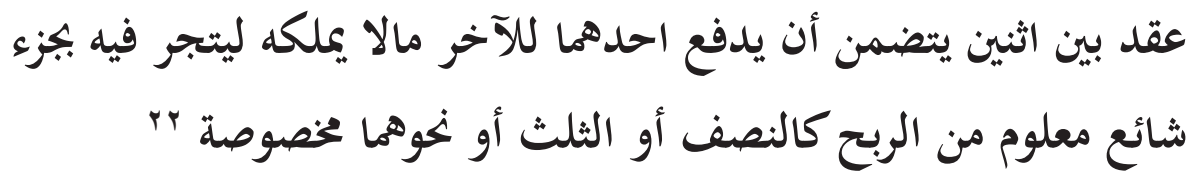

"Akad antara dua pihak yang saling menanggung, salah satu pihak menyerahkan hartanya kepada pihak lain untuk diperdagangkan dengan bagian yang telah ditentukan dari keuntungan, seperti setengah atau sepertiga dengan syarat-syarat yang telah ditentukan".

Menurut Ulama Hanafiyah akad mudhârabah ialah:

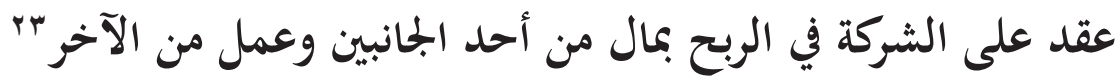

18 Teori keadilan yang dikemukan oleh Jhon Rawls paling komprehensif sampai saat ini yang berangkat dari pemikiran Utilitarianisme. Teori keadilannya banyak sekali dipengaruhi pemikiran Jeremy Bentham, J.S. Mill, dan Hume, yang dikenal sebagai tokoh-tokoh Utilitarianisme, sekalipun demikian, Rawls sendiri lebih sering dimasukkan dalam kelompok penganut Realisme Hukum.

19 Dimyauddin Djuwaini, Fiqh Muamalah, Pustaka Pelajar, Yogyakarta, 2008, hlm. 224.

20 Neneng Nurhasanah, Mudharabah, Refika Aditama, Bandung, 2015, hlm. 66.

21 Rachamat Syafe 'i, Fiqih Muamalah, Pustaka Pelajar, Bandung, 2001, hlm. 224.

22 Abd al-Rahman al-Jaziri, al-Fiqh alâ al-Madzâhib al-Arba'ah, Dâr al-Hadîts, Kairo, 2004, Juz. III, hlm. 32.

23 Ibn 'Abidin, Hasyiyah Rad al-Mukhtâr 'alâ al-Dar al-Mukhtâr Syarh Tanwîr al-Abshâr Fiqh Abû Hanifah, Dâr al-Fikr, Beirût, 2000, Juz. VIII, hlm. 277. 
"Akad perkongsian dalam hal keu Intungan, satu pihak sebagai pemilik harta (modal) dan pihak yang lain pemilik jasa".

Menurut Ulama Malikiyah akad mudhârabah ialah:

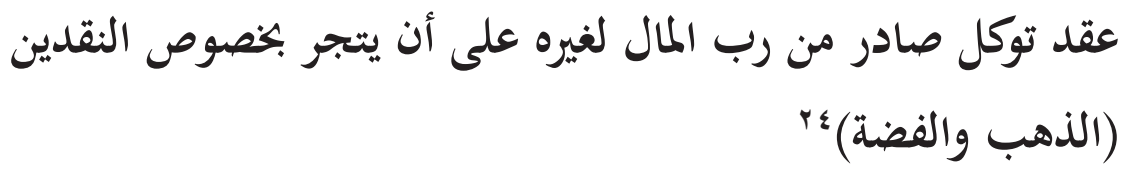

"Akad perwakilan, dimana pemilik harta mengeluarkan hartanya kepada yang lain untuk diperdagangkan dengan pembayaran yang ditentukan (mas dan perak).

Menurut Ulama Syafi'iyah akad mudhârabah ialah:

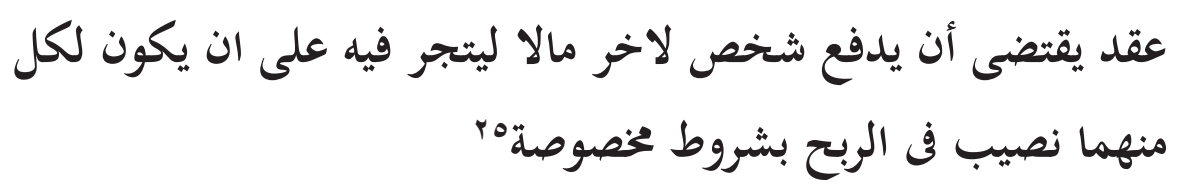

"Akad yang menentukan seseorang menyerahkan hartanya kepada pihak lain untuk diperdagangkan dan keduanya mendapat bagian dari keuntungan berdasarkan kesepakatan".

Menurut ulama Hanabilah akad mudhârabah ialah:

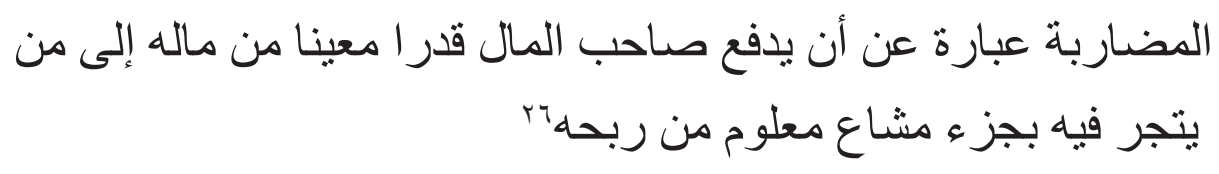

"Ibarat pemilik harta menyerahkan hartanya dengan ukuran tertentu kepada yang berdagang bagian dari keuntungan yang diketahui".

Menurut Kompilasi Hukum Ekonomi Syariah (KHES) ${ }^{27}$

Mudhârabah adalah kerja sama antara pemilik dana atau penanam modal dan pengelola modal untuk melakukan usaha tertentu dengan pembagian keuntungan berdasarkan nisbah.

24 Abd al-Rahman al-Jaziri, Loc. Cit., hlm. 35.

25 Ibid., hlm. 39.

26 Ibid., hlm. 37.

27 Kompilasi Hukum Ekonomi Syariah (KHES) merupakan upaya kaum muslim Indonesia untuk memberikan panduan bagi masyarakat yang berminat melaksanakan dan atau menjadi pelaku ekonom syariah di Indonesia. KHES pun dapat dijadikan pedoman bagi para penegak hukum apabila terjadi sengketa di bidang ekonomi syariah. Lihat, Juhaya S. Praja, Ekonomi Syariah, Pustaka Setia, Bandung, 2012, hlm. 197. KHES disusun oleh kelompk Kerja/Tim Penyusun "Kompilasi Hukum Ekonomi Syariah” berdasarkan surat Keputusan Ketua Mahkamah Agung Republik Indonesia No. KMA/097/SK/X/2006 tanggal 20 Oktober 2006 yang diketuai oleh Prof. Dr. H. Abdul Manan. Lihat, Mardani, Hukum Ekonimi Syariah, Refia Aditama, Bandung, 2011, hlm. 89. Buku Kompilasi Hukum Ekonomi Syariah (KHES) berlaku berdasarkan Keputusan Mahkamah Agung RI No. 2 Tahun 2008 tentang Kompilasi Hukum Ekonomi Syariah, yang terdiri atas empat buku, 796 pasal. Buku I tentang Subjek Hukum dan Harta (Amwâl) yang terdiri atas tiga bab dengan 19 pasal; Buku II tentang Akad, yang terdiri atas 29 bab dengan 655 pasal; Buku III tentang Zakat dan Hibah, terdiri atas empat bab dengan 60 pasal; Buku IV tentang Akuntansi Syariah, yang terdiri atas tujuh bab dengan 62 pasal. Lihat, Neneng Nurhasanah, Op. Cit., hlm. 205. 
Berdasarkan uraian para ulama di atas, dapat disimpulkan bahwa akad Mudhârabah adalah akad kerja sama usaha di antara dua pihak dimana pihak pertama (shâhib almâl) menyediakan seluruh (100\%) modal, sedangkan pihal lainnya menjadi pengelola. Secara mudhârabah, kentungan usaha dibagi menurut kesepakan yang dituangkan dalam kontrak. Apabila usaha tersebut mengalami kerugian, maka kerugian tersebut ditanggung oleh pemilik modal selama kerugian itu bukan akibat kelalaian si pengelola. Seandanya kerugian itu diakibatkan karena kecurangan atau kelalaian si pengelala, si pengelola harus bertanggung jawab atas kerugian tersebut. ${ }^{28}$

Akad mudhârabah memiliki beberapa rukun yang telah digariskan oleh ulama guna menentukan sahnya akad tersebut, rukun yang dimaksud adalah: 1) shâhib al-mâl (pemilik modal); 2) mudharib (pengelola); 3) shîghat (ijab kabul); 4) ra's al-mâl (modal); 5) pekerjaan, dan keuntungan. ${ }^{29}$

\section{Penerapan Prinsip Keadilan dalam Akad Mudrabah di Lembaga Keuangan Syariah}

Islam telah mengharamkan setiap hubungan bisnis yang mengandung kezhaliman dalam mewajibkan terpenuhunya keadilan yang teraplikasi dalam setiap hubungan dagang dan kontrak-kontrak bisnis karena sistem ekonimi Islam tidak menganiaya masyarakat terutama masyarakat lemah seperti dilakuakan oleh sistem kapitalis, tidak pula menganiaya hak-hak kebebasan individu, seperti yang dilakukan oleh komunis terutama marxisme. Ekonomi Islam adalah pertengahan diantara keduanya, tidak menyia-nyiakan dan tidak berlebih-lebihan, tidak melampaui batas dan tidak pula merugikan.

Kesenjangan pendapatan dan kekayaan alam yang ada dalam masyarakat berlawanan dengan semangat serta komitmen Islam terhadap persaudaraan dan keadilan sosial ekonomi. Kesenjangan harus diatasi dengan menggunakan cara yang ditekankan Islam. Diantaranya adalah dengan cara-cara berikut ini:

a. Menghapuskan monopoli, kecuali oleh pemerintah, untuk bidang-bidang tertentu.

1) Menjamin hak dan kesempatan semua pihak untuk aktif dalam proses ekonimi, baik produksi, distribusi, sirkulasi maupun konstitusi.

2) Menjamin basic needs fulfillment (pemenuhan kebutuhan dasar hidup) setiap anggota masyarakat.

3) Melaksanakan amanah al-takaaful al-ijima' $i$ atau social economic security insurance dimana yang mampu menaggung dan membantu yang tidak mampu.

Dengan cara itu standart kehidupan setiap individu akan lebih terjamin, sisi manusiawi dan kehormatan setiap individu akan lebih terjaga sesuai dengan martabat yang telah melekat pada manusia sebagai khalifah Allah dimuka bumi. Konsep keadilan Islam dalam distribusi pendapatan dan kekayaan serta konsep keadilan ekonomi menghendaki setiap individu mendapatkan imbalan sesuai dengan amal dan karyanya. Ketidaksamaan pendapatan dimungkinkan dalam islam karena kontribusi masing-masing orang kepada masyarakat berbeda-beda.

Sedangkan keadilan menurut Aristoteles yang dikenal dengan keadilan distributif, yaitu tensing soal pembagian barang-barang dan kehormatan pada masing-masing orang sesuai dengan statusnya dalam masyarakat. Keadilan ini menghendaki agar orang-orang yang mempunyai kedudukan yang sama memperoleh perlakuan yang sama pula dihadapan hukum. ${ }^{30}$ Sedangkan tujuan hukum menurut Jeremy Bentham yaitu untuk mewujudkan keadilan dan kebahagiaan yang sebesar-besarnya untuk sebanyak-banyaknya orang dan

28 M. Syafi'i Antonio, Bank Syari'ah dari Teori ke Praktik, Gema Insani Press, Jakarta, 2001, hlm. 95.

29 Dimyauddin Djuwaini, Op. Cit., hlm. 227.

30 Achmad Ali, Menguak Tabir Hukum, Ghalia Indonesia, Bogor, 2011, hlm. 198. 
tujuan dari perundang-undangan yaitu untuk menghasilkan kebahagiaan bagi masyarakat. Untuk itu, perundang-undangan harus berusaha untuk mencapai empat tujuan yaitu: untuk memberikan nafkah hidup, memberikan makanan yang melimpah, memberikan perlindungan, dan untuk mencapai persamaan. ${ }^{31}$

Sebelumnya, hal diatas telah dilakukan oleh Nabi Muhammad SAW, karena dalam setiap kebijakan ekonomi Nabi mementingkan keadilan yang bukan saja berlaku untuk kaum muslimin, tetapi berlaku juga untuk kaum lainnya sekitar Madinah. Terbukti, ketika diminta untuk menetapkan harga itu pada kekuatan pasar yang alami (bukan karena monopoli atau proteksi).

Prinsip-prinsip keadilan merupakan salah satu bentuk tindakan yang banyak disebutsebut dalam Al-quran, antara lain:

1) Surat Al-Maidah ayat 8 yang artinya:

"Hai orang-orang yang beriman hendaklah kamu menjadi orang-orang yang selalu menegakkan (kebenaran) karena Allah, manjadi saksi dengan adil. Dan janganlah sekali-kali kebencianmu terhadap suatu kaum mendorong kamu untuk berlaku tidak adil. Berlaku adillah, karena adil lebih dekat kepada takwa dan bertakwalah kepada Allah, sesungguhnya Allah Maha Mengetahui apa yang kamu kerjakan”.

2) Surat An-Nahl ayat 90 yang artinya:

"sesungguhnya Allah menyuruh (kamu) untuk berlaku adil dan berbuat kebajikan memberi kepada kaum kerabat, danAllah melarang dari perbuatan keji, kemungkaran dan permusuhan. Dia memberi pengajaran kepadamu agar kamu dapat mengambil pelajaran”.

Nilai keadilan dalam akad Mudharabah dua tingkat terletak pada keuntungan dan pembagian resiko dari masing-masing yang sedang melakukan kerjasama sesuai dengan porsi keterlibatannya. Kedua belah pihak akan menikmati keuntungan secara proporsional, jika kerjasama tersebut mendapatkan keuntungan. Sebaliknya, masingmasing pihak menerima kerugian secara proforsional, jika usaha yang digalang bersama tidak mendapatkan hasil. Dari aspek pemodal resikonya adalah kehilangan uang yang diinvestasikan. Dan dari pihak mudharib ia menerima resiko berupa kehilangan tenaga dan pikiran dalam melakukan pengelolaan modal. ${ }^{32}$

Menurut Chapra, salah satu masalah utama dalam kehidupan sosial dimasyarakat adalah mengenai cara melakukan pengalokasian dan pendistribusian sumber daya yang langka tanpa harus bertentangan dengan tujuan makro ekonominya. Tanpa adanya keseimbangan ini, maka masyarakat mungkin akan menghadapi berbagai masalah. Misalnya, ketika terlalu banyak proporsi sumber daya yang dialokasikan untuk komsumsi, maka tabungan dan tingkat investasi yang ada mungkin tidak cukup dapat mewujudkan kesempatan kerja penuh, dan tingkat pertumbuhan ekonomi yang optimal. ${ }^{33}$

Dalam upaya untuk mewujudkan perbankan syariah yang sehat yang dapat memenuhi kebutuhan masyarakat serta berkontribusi dalam mendorong terciptanya ketahanan sistem perbankan dan pembangunan nasional, Bank Indonesia telah melakukan berbagai langkah sesuai dengan fungsi dan perannya sebagai otoritas perbankan.

Sejak awal pengembangan Perbankan Syariah Nasional sejumlah critical issue yang perlu menjadi perhatian guna menjamin terciptanya sasaran pengembangan perbankan syariah telah diidentifikasi, antara lain adalah: i) Penyempurnaan peraturan dan perundang-

31 Ibid., hlm. 204.

32 M. Yazid Afandi, Fiqh Muamalah dan Implementasnya dalam Lembaga Keuangan Syariah, Logung Pustaka, Yogyakarta, 2009, hlm. 101-102.

33 Eko Suprayitno, Ekonomi Islam: Pendekatan Ekonomi Makro Islam dan Konvensional, Graha Ilmu, Yogyakarta, 2005, hlm. 16. 
undangan yang sesuai dengan karakteristik usaha perbankan syariah, ii) Pertumbuhan jaringan kantor yang dapat memenuhi kebutuhan masyarakat yang semakin meningkat terhadap jasa perbankan syariah, iii) Meningkatkan pemahaman masyarakat terhadap perbankan syariah, iv) Tersedianya infra struktur dan lembaga pendukung yang dapat mendorong perkembangan perbankan syariah, v) Meningkatnya efisiensi operasi, mutu pelayanan dan daya saing perbankan syariah nasional, vi) Mendorong perkembangan pembiayaan sistem bagi hasil dalam proporsi yang memadai dalam portofolio dalam pembiayaan Bank Syariah, dan, vii) Terciptanya Bank Syariah yang memiliki kompetensi, profesionalisme dan dapat memenuhi standart yang ditetapkan secara internasional.

Transaksi yang berbasis bunga melanggar keadilan atau kewajaran bisnis. Dalam bisnis, hasil dalam setiap perusahaan selalu tidak pasti. Namun dalam sistem bunga, peminjam sudah berkewajiban untuk membayar tingkat bunga yang disetujui walaupun perusahaannya mungkin rugi. Bahkan meskipun perusahaan untung, bisa jadi bunga yang harus dibayarkan melebihi keuntungannya. Hal ini jelas bertentangan dengan norma keadilan dalam Islam. Maka, untuk menciptakan pendistribusian pendapatan secara adil, maka Perbankan Syariah masih mengacu pada hukum perdata secara umum, terutama mengenai perjanjian-perjanjian yang dilakukan oleh kedua belah pihak. Tujuannya untuk adanya kepastian hukum.

Sedangkan, hubungan hukum antara bank dengan nasabahnya terjadi ketika nasabah dan bank sepakat untuk mengikatkan diri dalam perjanjian pembiayaan Musyarakah. Dalam hal perjanjian pembiayaan, Pasal 1313 KUHPerdata menentukan bahwa"perjanjian adalah suatu perbuatan dengan mana satu orang atau lebih mengikatkan dirinya terhadap suatu orang atau lebih lainnya". Subekti mengartikan perjanjian sebagai suatu peristiwa dimana seseorang berjanji kepada seorang lain atau dimana dua orang itu saling berjanji untuk melaksanakan suatu hal. ${ }^{34}$ Sedangkan Abdul Kadir Muhammad mengatakan bahwa perjanjian sebagai suatu persetujuan dengan mana dua orang atau lebih saling mengikatkan diri untuk melaksanakan suatu hal dalam lapangan harta kekayaan. ${ }^{35}$

Sedangkan Mariam Darus Baduzzaman berpendapat bahwa perjanjian kredit bank adalah perjanjian pendahuluan dari perjanjian penyerahan uang. Perjanjian pendahuluan ini merupakan hasil pemufakatan antara pemberi dan penerima kredit. ${ }^{36}$

Disamping itu, pasal 1338 ayat (1) KUHPerdata menentukan bahwa "semua persetujuan yang dibuat secara sah berlaku sebagai undang-undang bagi mereka yang membuatnya. Dengan kata lain, jika Bank Syariah dan nasabah membuat perjanjian yang bentuk formalnya didasarkan pada pasal 1320 dan 1338 KUHPerdata, tetapi isi,materi, atau substansinya didasarkan atas ketentuan syariah, maka perjanjian tersebut dapat dikatakan sah baik dilihat dari sisi hukum nasional maupun dari sisi syariah. ${ }^{37}$

Dilihat dari kontra prestasi, maka dengan demikian kredit atau pembiayaan berdasarkan prinsip syariah merupakan perjanjian pinjam meminjam (uang) yamg dilakukan antara bank dengan nasabah. Perjanjian pinjam meminjam (uang) itu dibuat atas dasar kepercayaan bahwa peminjam dalam tenggang waktu yang telah ditentukan akan melunasi atau mengembalikan pinjaman uang atau tagihan tersebut kepada bank disertai pembayaran sejumlah bunga, imbalan atau pembagian hasil keuntungan sebagai imbalan jasanya. ${ }^{38}$

34 Subekti, Jaminan Untuk Pemberian Kredit Menurut Hukum Indonesia, Citra Aditya Bakti, Bandung, 1991, hlm. 1.

35 Abdulkadir Muhammad, Hukum PErikatan, Alumni, Bandung, 1982, hlm. 78.

36 Mariam Darus Badruzzzaman, Perjanjian Kredit Bank, Citra Aditya Bakti, 1998, hlm. 30.

37 Hartono Mardjono, Petunjuk Praktis Menjalankan Syriat Islam Dalam Bermuamalah yang Sah Menurut Hukum Nasional, Studia Press, Jakarta, 2000, hlm. 24.

38 Hessel Nogi S. Tangkilisan, Mengeola Kredit Berbasis Good Corporate Governance, Balairung \& Co, Yogykarta, 
Begitu juga, perjanjian tertulis diperlukan perbankan syariah untuk menjamin kepastian hukum sehingga dapat menciptakan rasa keadilan kepada para penabung dalam melakukan fungsi yang bermanfaat kepada warga masyarakat pada umumnya dan khususnya warga masyarakat islam yang membutuhkan dana. Membuat perjanjian secara tertulis akad perjanjian tabungan mudharabah disebut nisbah bagi hasil pemilik dana (shahibul mal) dan untuk pengelola dana (mudharib). Nisbah bagi hasil berlaku sampai berakhirnya perjanjian. Perjanjian ini mengikat dan merupakan satu kesatuan yang tidak dapat dipisahkan dengan syarat-syarat dan ketentuan umum. ${ }^{39}$

Sesuai dengan visi perbankan syariah yang berbunyi: terwujudnya sistem perbankan syariah yang kompetitif, evisien, dan emenuhi prinsip kehati-hatian yang mampu mendukung sektor riil secara nyata melalui kegiatan pembiayaan berbasis bagi hasil (share based financing) dan transaksi riil dalam kerangka keadilan, tolong menolong menuju kebaikan guna mencapai kemaslahatan masyarakat.

Keadilan dalam pendistribusikan pendapatan ini merupakan perintah langsung yang harus dilakukan oleh perbankan syariah untuk dilaksanakan. Keadilan dalam pendistribusian pendapatan memeng menempati posisis sebagai nilai yang tertinggi, tetepi dalam penjabarannya tetap menggunakan kata adil, sekalipun sudah berada pada tataran praktis. Dengan demikian, tujuan dari perbankan syariah untuk menunjang pelaksanaan pembangunan nasional dalam rangka meningkatkan keadilan, kebersamaan dan pemerataan kesejahtraan rakyat dapat tercapai.

Meskipun ada faktor-faktor yang signifikan serta faktor-faktor pendukung konsep mudharabah dua tingkat dalam Undang-Undang No. 21 tahun 2008 tentang perbankan syariah, tetapi masih ada kelemahan-kelemahan yang harus dihadapi oleh perbankan syariah didalam prakteknya yatu sebagai berikut:

1) Terlalu berprasangka baik terhadap semua nasabah dan berasumsi bahwa semua orang yang terlibat jujur dan dapat dipercaya, sehingga rawan terhadap itikad buruk.

2) Metode bagi hasil memerlukan perhitungan yang rumit, terutama dalam menghitung bagian laba nasabah yang kecil-kecil dan nilai simpananya tidak tetap. Risiko adalah hitung lebih besar daripada di bank konvesional.

3) Produk-produk bank syariah belum mengakomodasi kebutuhan masyarakat dan kurang kompetitif, kerena manajemen bank syariah cenderung mengadopsi produk perbankan konfensional yang disyariahkan dengan variasi produk yang terbatas.

4) Menurut Gubernur Bank Indonesia Halim Alamsyah saat membuka musyawarah nasional asosiasi perbankan syariah Indonesia di jakarta, rabu 21 maret 2012 menyatakan bahwa ada tiga tantangan yang dihadapi industry perbankan syariah di Indonesia. Tantangan itu adalah kwantitas dan kualitas sumber daya manusia, inovasi produk dan layanan manusia, inovasi produk dan layanan dan kompetitif, serta keberlangsungan program edukasi dan sosialisasi. Selama ini produk perbankan syariah masih banyak yang belum terisolasikan kemasyarakat. Akibatnya, peminat produk tersebut masih sangat minim.

5) Pemahaman masyarakat yang kurang mengerti terhadap kegiatan oerasional bank syariah.

6) Peraturan perundang-undangan mengenai perbankan belum sepenuhnya mengakomodir operasional bank syariah.

7) Kepastian hukum tentang mekanisme penyelesaian sengketa Undang-Undang Perbangkan syariah belum memuat secara pasti mekanisme penyelesaian sengketa yang dapat terjadi antara nasabah dan syariah terutama mengenai lembaga peradilan yang bertanggung jawab mengurus tentang sengketa tersebut. 
8) Batasan yang jelas antara peran BI dan DSN MUI, perlu kejelasan lebih lanjut dalam pembagian tugas antara BI dan DSN MUI dalam perananya sebagai pengawas sekaligus regulator dalam pelaksanaan operasionalisasi perbankan syariah di Indonesia. Kejelasan ini perlu agar tidak terjadi benturan kewenangan UndangUndang Perbankan Syariah diberlakukan.

\section{KESIMPULAN}

Berdasarkan uraian dan pemaparan serta analisis di atas, maka dalam tulisan ini dapat ditarik beberapa simpulan sebagai berikut: (1) Aristoteles membedakan keadilan itu menjadi 2 macam:,pertama, keadilan distributif; dan kedua, keadilan kumulatif. Mudhârabah adalah kerja sama antara pemilik dana atau penanam modal dan pengelola modal untuk melakukan usaha tertentu dengan pembagian keuntungan berdasarkan nisbah; (2) prinsip keadilan yang dapat diterapkan dalam akad mudharabah pada lembaga keuangan syariah adalah keadilan distributif. Perlu adanya pengawasan yang inetensif guna terselenggaranya transaksi mudharabah yang sesuai dengan prinsip hukum Islam dan demi terwujudnya nilai keadilan bagi kedua belah pihak.

\section{DAFTAR PUSTAKA}

Abd al-Rahman al-Jaziri, al-Fiqh alâ al-Madzâhib al-Arba'ah, Dâr al-Hadîts, Kairo, 2004.

Abdulkadir Muhammad, Hukum Perikatan, Alumni, Bandung, 1982.

Abul Aziz Dahlan (ed al), Ensiklopedia Hukum Islam I, Ikhtiar Baru van Hoevem Jakarta, 2000.

Achmad Ali, Menguak Tabir Hukum, Ghalia Indonesia, Bogor, 2011.

Departemen Pendidikan Nasional, Kamus Besar Bahasa Indonesia, Balai Pustaka, Jakarta, 2005.

Dimyauddin Djuwaini, Fiqh Muamalah, Pustaka Pelajar, Yogyakarta, 2008.

Eko Suprayitno, Ekonomi Islam: Pendekatan Ekonomi Makro Islam dan Konvensional, Graha Ilmu, Yogyakarta, 2005.

Hartono Mardjono, Petunjuk Praktis Menjalankan Syriat Islam Dalam Bermuamalah yang Sah Menurut Hukum Nasional, Studia Press, Jakarta, 2000.

Ibn 'Abidin, Hasyiyah Rad al-Mukhtâr 'alâ al-Dar al-Mukhtâr Syarh Tanwîr al-Abshâr Fiqh Ab̂̂u Hanifah, Dâr al-Fikr, Beirût, 2000.

M. Syafi'i Antonio, Bank Syari'ah dari Teori ke Praktik, Gema Insani Press, Jakarta, 2001.

M. Yazid Afandi, Fiqh Muamalah dan Implementasnya dalam Lembaga Keuangan Syariah, Logung Pustaka, Yogyakarta, 2009.

Mardani, Hukum Ekonimi Syariah, Refia Aditama, Bandung, 2011.

Mariam Darus Badruzzzaman, Perjanjian Kredit Bank, Citra Aditya Bakti, 1998.

Neneng Nurhasanah, Mudharabah, Refika Aditama, Bandung, 2015.

Heri Sudarsono, Bank dan Lembaga Keuangan Syariah: Deskripsi dan Ilustrasi, EKONISIA, Yogyakarta, 2008.

Hessel Nogi S. Tangkilisan, Mengeola Kredit Berbasis Good Corporate Governance, Balairung \& Co, Yogykarta, 2003.

Nindyo Pramono, Bunga Rampai Hukum Bisnis Aktual, PT Citra Aditya Bakti, Bandung, 2006.

Rachamat Syafe'i, Fiqih Muamalah, Pustaka Pelajar, Bandung, 2001. 
Rohi Baalbaki, AL-Mawrid, Dar al-'Ilmi lil Malayin, Beirut, 2007.

Subekti, Jaminan Untuk Pemberian Kredit Menurut Hukum Indonesia, Citra Aditya Bakti, Bandung, 1991.

The Liang Gie, Teori-Teori Keadilan, Supersukses, Yogyakarta, 1982.

Warkum Sumitro, Asas-Asas Perbankan Islam dan Lembaga-Lemabaga Terkait, PT RajaGrafindo Persada, Jakarta, 1996.

Yadi Janwari, Lembaga Keuangan Syariah, Remaja Rosdakarya, Bandung, 2015.

Zainuddin Ali, Hukum Perbankan Syariah, Sinar Grafika, Jakarta, 2008.

Zainul Arifin, Dasar-Dasar Manajemen Bank Syariah, Alvabet, Jakarta, 2002. 